\title{
The Economic and Social Impact of GMOs in China
}

\section{Zhang Tao et Zhou Shudong}

\section{OpenEdition}

\section{Journals}

Édition électronique

URL : http://journals.openedition.org/chinaperspectives/359

DOI : 10.4000/chinaperspectives.359

ISSN : 1996-4617

\section{Éditeur}

Centre d'étude français sur la Chine contemporaine

\section{Édition imprimée}

Date de publication : 1 juin 2003

ISSN : 2070-3449

\section{Référence électronique}

Zhang Tao et Zhou Shudong, "The Economic and Social Impact of GMOs in China », China Perspectives [En ligne], 47 | May-june 2003, mis en ligne le 10 novembre 2006, consulté le 28 octobre 2019. URL : http://journals.openedition.org/chinaperspectives/359; DOI : 10.4000/chinaperspectives. 359

Ce document a été généré automatiquement le 28 octobre 2019

(c) All rights reserved 


\title{
The Economic and Social Impact of GMOs in China
}

\author{
Zhang Tao et Zhou Shudong
}

1 The use of modern biotechnology to create genetically modified organisms (GMOs) is allowing our main food agricultural crops to be altered in ways that were not believed possible even by specialists who took part in the green revolution only decades ago. Agriculture and food production are going through another revolution, the current technology of moving individual genes through biotechnology-genetic engineering. Plants and animals have been modified to resist pests and diseases. Even though agricultural biotechnology has rapidly improved, its deployment and impact are a matter of some controversy. In China, genetic engineering is seen as a possible way of boosting China's food security, and lessen the impact of industrialization, which diminishes the availability of agricultural land.

2 However, GMOs have also attracted criticism and concern with regard to the safety of consuming them, the environmental impact of growing genetically modified plants, and the social ethics of using this technology. The champions of biotechnology such as Monsanto and the Biotechnology Industry Organisation see agricultural biotechnology as a tool to help solve problems of hunger and excessive pesticide use. The critics of biotechnology say that plant biotechnology is not needed, is a risk to consumers' health, only fattens the profits of companies such as Monsanto, and will reduce biodiversity. The controversy is of particularly importance to China as a developing country that has not yet decided whether or not to allow the wide use of GMOs. China has in fact just allowed the wide planting of Bt cotton (Bacillus thuringiensis) which is not an edible plant.

3 The aim of this paper is to measure the ramifications of the use of GM products for society and for the economy in China.

Production and research of GM plants in China

4 China has greatly increased its crop production after the 1970s through an increased use of agricultural chemicals. 
5 The greater use of pesticides certainly has helped China raise production. It has also had a number of adverse consequences. Pesticides pose a serious danger to soil and water quality and thus to the agro-ecosystem. The negative effects and social costs in some cases may exceed the cost of purchasing the pesticides. Acknowledging the negative effects of excessive pesticide use, China's government has made efforts to regulate pesticide production, marketing and application since the 1970s. Real reductions in the use of pesticides may have to depend on alternative approaches, such as the adoption of the host-plant resistant varieties. As a result, China has followed the example of the United States and started developing crops genetically engineered to be resistant to major pests.

6 Since the early 1980 s, China has led about 130 projects focusing on GMOs, covering more than one hundred kinds of genes, including 47 kinds of plants, four kinds of animals and 31 kinds of microbes. China was the first country in the world to begin growing GM crops commercially, starting with virus-resistant tobacco plants in 1988. In recent years, the Chinese Government has given continuous and increasing support to the biotechnology research programme and actively enhancing research in agricultural biotechnology. Currently, more than one hundred laboratories across the country are researching the gene sequences of crops, animals and humans. This means $90 \%$ of China's field trials targeting pest and disease resistance. From 1991 to 2002 six or so GMOs have been approved for commercial use related to tomato, sweet pepper, cotton, tobacco and petunia growing. The Ministry of Agriculture has also granted more than six licences for their commercial production including two for bollworm-resistant cotton, two for slow-ripening and virus-resistant tomatoes, and one each for sweet pepper and petunias. In China's new Five-Year Plan for 2001-2005, the government will focus further on the commercialisation of scientific innovations, especially genetic engineering.

7 Currently, China accounts for more than half of the developing world's investment in plant biotechnology. However compared with the developed world whose spending is about US $\$ 2$ to $\$ 3$ billion, China's spending has been relatively small. While in other parts of the world most plant biotechnology research projects are privately financed, those in China are financed largely by the government. In 1999, China's total expenditure on plant biotechnology was estimated to be US $\$ 112$ million ${ }^{2}$. China's biotechnology research budget in 2001 was triple the budget of US\$120 million in 2000 . Furthermore, Chinese officials have announced that the budget for such research will be increased by as much as $400 \%$ before 2005 .

8 Meanwhile, increases in China's agricultural biotechnology research staff have been among the greatest in developing countries. There are about one hundred and fifty laboratories at the national and local level located in more than fifty research institutes and universities across the country working on agricultural biotechnology. The number of scientists and professional staff rose from 740 in 1986 to 1,988 in 19993. There has also been a marked improvement in the formal education and training of those engaged in biotechnology research.

9 Rice being the most important crop in China, in 1997 China's researchers began using $\mathrm{AC} / \mathrm{DS}$ transposons and T-DNA insertion methods to create rice mutagenesis pools. And in 2001, the China Academy of Sciences initiated a major research programme to develop rice varieties that include Bt and CpTI genes, which are resistant to the stem borer (Chilo suprasselis), and Xa21 genes which are resistant to plant-hopper 
(Nilaparvata lugens) and bacterial leaf blight. At present, the herbicide-resistant rice (barsta-transgenic bacterial-blight-resistant rice) developed by China has passed the environment safety evaluation release stage and is ready for production testing, and is at the stage of field experimentation. The China Academy of Science's 2003 programme will develop and analyse new genes to find those that can produce rice varieties with a high yield and of high quality. At the same time, scientists will develop the study of the Single nucleotide polymorphism (SNP) of China rice resources and set up the rice gene databank. In 2004, the project will develop and patent 1,000 rice genes. Other projects include the study of genes of long-grained rice. Recently, some varieties of genetically modified rice have been tested in experimental fields regulated by the Ministry of Agriculture-Waxy rice, Bar rice and Xa21 rice, inserted with the new Waxy, Bar and Xa21 genes-and which have undergone at least three years of environmental release trials. The China National Rice Research Institute in Hangzhou, Zhejiang province, is spearheading the research, opting to engineer rice plants that produce higher yields and high quality rice and which are more drought- and pest-resistant. In 2001, a herbicide-resistant GM rice was approved for release and began selling on a trial basis in several counties (xian) in eastern Zhejiang province.

In corn research, pest-resistant transgenic corn and corn with a high lysine content have undergone small-scaled experiments. As for soybean research, the transgenic aphis-resistant soybean and soybean-moth-resistant transgenic Bt soybean have been approved for environmental release. In addition, China has implemented in recent years some important programmes to develop industries centred around high technologies, such as the development of genetically engineered vaccine production. With respect to applying GMO research achievements in agriculture as soon as possible, from 1997 to 2001, the Ministry of Agriculture approved ten genetically modified plants for field environment release, among them, rice, corn, cotton, soybean, rape, potato and a poplar tree. Jiangsu, an important province for field trials and environment release, undertook the testing and evaluation of 27 kinds of GMOs including plants, animals and microbes.

11 With regard to the research on cotton, the only GMO crop largely cultivated in China, 45 improved varieties have been approved for environment release. Of these, 13 varieties, including GK19 and Zhongmian 38, have been examined by the national government and confirmed as pest-resistant, high-yielding and quality cotton varieties. These have been put into production in 12 provinces, their growing area being over 600,000 ha. in 2001.

Among them, Bt cotton is the most extensively grown transgenic crop in China today: Bt cotton accounts for one fourth of China's total cotton production. As early as 1991, the biotechnology research centre of the China Academy of Agricultural Sciences (CAAS) initiated a research programme to develop cotton varieties resistant to cotton bollworms. By 1993 the first successful genetically modified cotton variety was produced in China. Four years later, the Ministry of Agriculture approved the commercial use in nine provinces of cotton varieties that were genetically modified with a Bt gene to produce the toxin that kills bollworms. Monsanto introduced an American variety that had been genetically engineered. At the same time, the Institute of Biotech Research of CAAS introduced and extended four local cotton varieties that were engineered to include the Bt gene. An estimated one million hectares of Bt cotton were planted in China in 1999. Bt cotton plants have provided a $60 \% \sim 80 \%$ decrease in 
the use of foliar insecticides. Bt cotton growers in Shandong province earned US $\$ 930$ per ha in 1998, more than for non-Bt varieties.

To examine the impact of biotechnology on the production of cotton, we collected our own set of data in 2001 in Jiangsu province ${ }^{4}$ and compared them with data collected in 1999 and 2000 in Shandong and Hebei. In the short term, the economic result of Bt cotton is more effective than ordinary cotton. The major differences between Bt cotton and non-Bt cotton production is in the use of pesticides and the high yield of Bt cotton. From data collected by CAAS, Bt cotton farmers apply pesticide only 6.6 times per season compared to nearly 20 times per season by non-Bt cotton farmers, and on a perhectare basis the pesticide use of non-Bt cotton production was more than five times higher than Bt cotton in terms of both quantity and expenditure in 1999. The data in tables showed that the use of Bt cotton substantially reduced farmers' use of pesticides and increased their income. Farmers continued to spray for early season incidence of pests but could substantially reduce or eliminate their use of pesticides to control bollworm mid and late season. Some farmers reduced the number of times they sprayed from 30 to three times. However, from our own collected data in 2001, the difference between Bt cotton and non-Bt cotton production is not as large as the difference indicated by the data collected by CAAS.

One possible answer ${ }^{5}$ to this drop may be the different varieties of Bt cotton. In our survey we found that the yields of Bt cotton produced by the Monsanto corporation are higher those of Bt cotton produced by Chinese corporations and research institutes. There have been cases in Jiangsu province where some varieties of Bt cotton have shown a loss of their pest-resistant characteristics which has led to farmers threatening to indict the producers of these seeds. The difference in varieties and quality across Bt cotton seed could account for the as yet unexplained drop in net income for Bt cotton between 2000 and 2001 (see tables 1,2 \& 3).

Food safety and trade

15 Although many articles state that there is no evidence that genetically modified foods are not safe to eat, this also implies that there is no evidence that GM foods are safe to eat. The main concerns are the potential toxicity, allergenicity, lack of nutritional content and the safety of the newly introduced proteins. To provide a reasonable certainty that no harm will result, several types of data and long-term studies are required. Some simple experiments and tests have attempted to demonstrate that the protein in GM foods breaks down into small peptides or amino acids in in vitrodigestion. However, the tests provide no information on toxicity and the result from the aggregate exposure to these proteins.

16 An experiment reinforced recent concerns about the possible adverse health effects after exposure to transgenic foods. In this case, Losey, Raynor and Carter reported that Bt corn, a kind of GM plant, may be a hazard for monarch butterfly larvae ${ }^{6}$. They deposited some unspecified Bt corn pollen onto milkweed leaves and made the larvae feed on these leaves. After a four-day period, the researchers found a lower survival rate of larvae feeding on leaves deposited with Bt pollen than larvae feeding on control leaves without pollen. Although this report only used monarch butterfly larvae as its target organism, it indicated that GM foods might be pose a potential health risk to humans. Even specialists who support the spread of GM foods have noted that it is impossible to provide assurance of absolute-zero risk because of the inadequacy of methods to screen for toxicity and allergenicity. Hence, the importance and need to 
understand the various effects of deployment of GM foods on human health. A traditional risk assessment for GM foods involves four steps, hazard identification, dose-response evaluation, exposure assessment and risk characterisation. Although scientists may assert that risk assessments are needed for decisions, they are not easily explained to the general public. The elemental debate about the use of genetic engineering includes food safety and human health which is an essential issue in this debate.

In recent years Europeans in particular have become increasingly worried about food safety. Since the outbreak of mad-cow disease in 1996, the occurrence of dioxincontaminated Belgian chickens and the later recall of contaminated cans of Coca-Cola in France and the Benelux nations, health officials have grown fussier about what their citizens consume. Even though the EU has approved the sale of around eighteen GM products since 1990, it has as yet banned the importation of non-approved GM corn. The resistance to GM production also led to a de facto moratorium on authorisation of new releases of GMOs in western Europe. Before the imposition of the moratorium, releases of GMOs were reviewed on a case-by-case basis and had to be confirmed at every step. The Cartagena Protocol on Biosafety, ratified? in Montreal on 29 January 2000 , have added to a future trade dispute about GMO products. The Biosafety Protocol not only confirms the rights of signatory countries to set their own domestic regulations, but also allows each country to decide whether and under what conditions it will accept imports of GMO products. These import restrictions could apply to GMO products intended as food or for processing. Not only did the EU as a rich region, and Japan as a developed country seek import restrictions, some developing countries supported them. However, an essential aspect of the Biosafety Protocol, which is open to interpretation, is its relationship with the WTO agreements. Ostensibly, the Protocol's objective of protecting human health from the potential risk of GMO products is consistent with the WTO agreements, which acknowledges the necessity of enforcing trade-restricting measures to protect human health and public safety. But the key goal of the WTO is to achieve reasonable and effective use of the world's resources by reducing barriers to international trade. Members of the WTO are also bound under other WTO agreements that restrict trade measures that can be applied to restrict imports which can include GMOs. Now, with the decreasing use of such methods as tariffs and quantitative restrictions against imports, the technical barriers to trade are increasing. Although the WTO agreements aim at ensuring that technical measures are no more restrictive than necessary to meet objectives, they are used unduly in some cases. Moreover, currently, there are no strict international standards for GMO products, a situation that may lead to trading disputes. Most countries consider the need for developing standards for their own reasons and interests in consultation with other relevant international bodies such as the FAO and OECD. The US government views GM corn portents in foods as mere additives and thus does not require the Food and Drug Administration to approve them. Instead, it subjects them to a less formal review, a relatively low high bar that is easy to clear. However, the EU views GM products as a potential hazard to human health. These different attitudes and approaches to regulating GMO products and the absence of international standards mean trade disputes and barriers with regard to GMO products are a distinct possibility. Essentially, some countries in the Biosafety Protocol acknowledge that the lack of scientific evidence concerning potential adverse effects of GMOs cannot prevent 
them from stipulating stricter measures to restrict the import of GMOs for their possible risks. This could in so many words be saying "better safe than sorry".

Table 1: Data for Shandong in 1999 (yuan/ha)

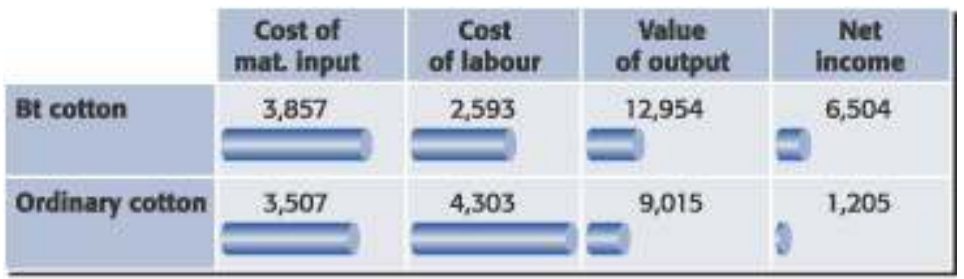

Source: CAAS

Table 2 : Data for Hebei in 2000 (yuan/ha)

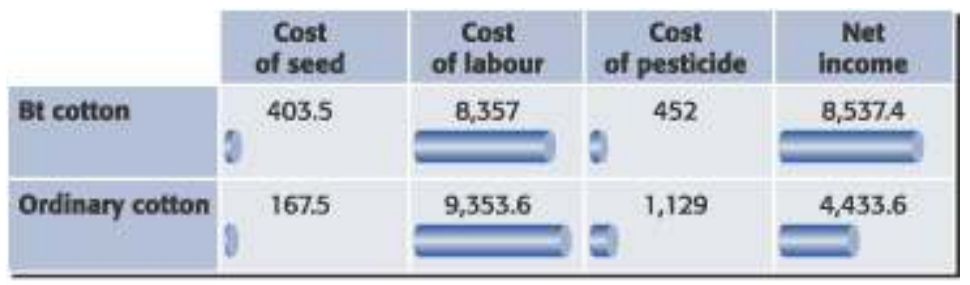

Source: CAAS

Table 3 : Data for Jiangsu in 2001 (yuan/ha)

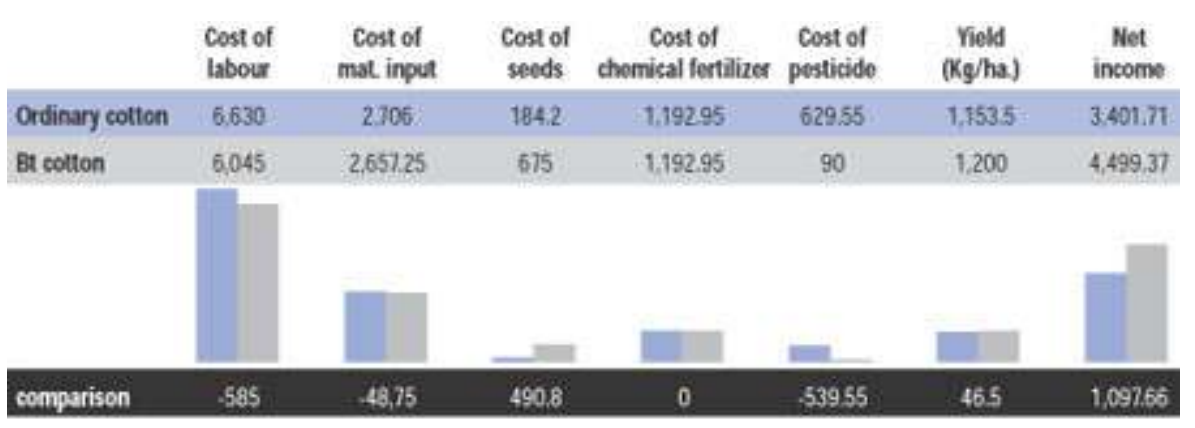

Source : author's survey.

China tends to restrict imports of GMO products, even though it has itself been planting GM cotton for the past five years. Given that Bt cotton plants produce plant fibres which are not for consumption, they do not pose a direct potential hazard to human health. With the risk of trade disputes, China, as a member of the WTO needs to assess the economic stakes where GMO products are concerned. Japan and South Korea now import Chinese ordinary soybeans instead of GM soybeans from the US. The economic stakes are how large the potential gains from widespread adoption of GMO in China could be, and how much china might lose if it accepted the widespread adoption of GMOs. Scientific evidence is not sufficient to constitute a basis upon which policy decisions can be made. In such cases, China as a member of the WTO can restrict imports of GMO products on the basis of available information. The principle of precautionary measures is a pertinent approach to uncertainties about genetically modified products, but it can be used by domestic groups competing to import who 
want to protect themselves from international competition. Therefore, it is very difficult to assess whether a measure is reasonable or just a form of hidden protectionism. There are other factors that can influence the decision-makers. One is potential out-crossing from GM plants to other organisms. Some scientists state that there is a possibility of a GM plant's traits being passed to related species. Importantly, the greater amount of pollen in commercial crops indicates a greater likelihood of cross-pollination by a GM plant. In the US, GM strains are mixed with ordinary strains very easily, so all US corn exports to Europe were effectively outlawed because of European restrictions on GM corn. The same also occurred in China when the ordinary corn exported to South Korea was found mixed with GM corn. In this trade case, South Korea discovered corn with GM corn traits perhaps contaminated by GM corn pollen. This case led to a stricter examination of China's corn exports to South Korea. The Chinese government must now take this into account in order to keep its export regions open. Even though China has postponed implementing its stricter regulations on the import of GM products, it is balancing all these factors more carefully now. The Chinese government is currently applying further restrictions to the import of GMO food products including GM soybeans and GM corn(maize).

On May $23^{\text {rd }}$ 2001, China issued the Regulations on the Safe Management of Agro-GMOs. The regulations now also govern research and experimentation, production, processing and operation as well as imports and exports. They stipulate that systems to ensure safety evaluation, labelling management production and operation licencing, as well as examination and approval for the safe importation of GMOs should be put in place. To ensure the implementation of the regulations the Ministry of Agriculture has adopted three supporting administrative measures. On January $5^{\text {th }} 2002$, the Ministry of Agriculture issued the Administration Measures on the Safety Evaluation of the Safety of Agro-GMOs, the Administration Measures on Safe Importation of Agro-GMOs, and the Administration Measures on the Labelling of Agro-GMOs, which came into force on March $20^{\text {th }}$ 2002. The Ministry of Agriculture is responsible for the research in important issues relating to the administration of the safety of Agro-GMOs. The Ministry has also set up the Office for the Administration of the Safety of Agro-GMOs, to be responsible for this area of work. In order to meet the requirements for entering into the WTO and set a transparent and fair process of evaluation of the safety on AgroGMOs and process for the application and approval of importation and labelling, the Ministry of Agriculture has formulated four normative documents, namely the Administration Procedures for the Evaluation of the Safety of Agro-GMOs, the Administration Procedures for Importation of Safe Agro-GMOs, the Certification and Approval Procedures for the Labelling of Agro-GMOs, and the Administration Procedures for the Temporary Certification of Agro-GMOs-these procedures were drafted to mollify the averse attitude of the US government and traders, and allow "temporary certification of imported GM products" by the Chinese Ministry of Agriculture in 30 days instead of 270 days. These four documents stipulate requirements and time limits for applications and official written replies. The new rules require all imported genetically modified soybeans, corn, rapeseed, cotton seed and tomatoes to be clearly labelled as genetically modified products. Furthermore, overseas firms that export genetically modified products to China must obtain certificates from China's Ministry of Agriculture as verification that their goods are safe. However, the Administration Measures on the Labelling of Agro-GMOs have not been effective. Labels have not been found on such products throughout the market. 
Besides being seen as an undertaking on the part of the Chinese government of its responsibility to maintain biological diversity, and protect the ecological environment and people's health, the above new rules regulating GMO agricultural imports are widely perceived to be non-tariff barriers to protect its farm sector from the impact of increased foreign imports and a result of the government's fear that China's inefficient soybean processing industry is expected to be hurt by membership of the WTO.

Table 4 : Consumer reactions to GM products (en \%)

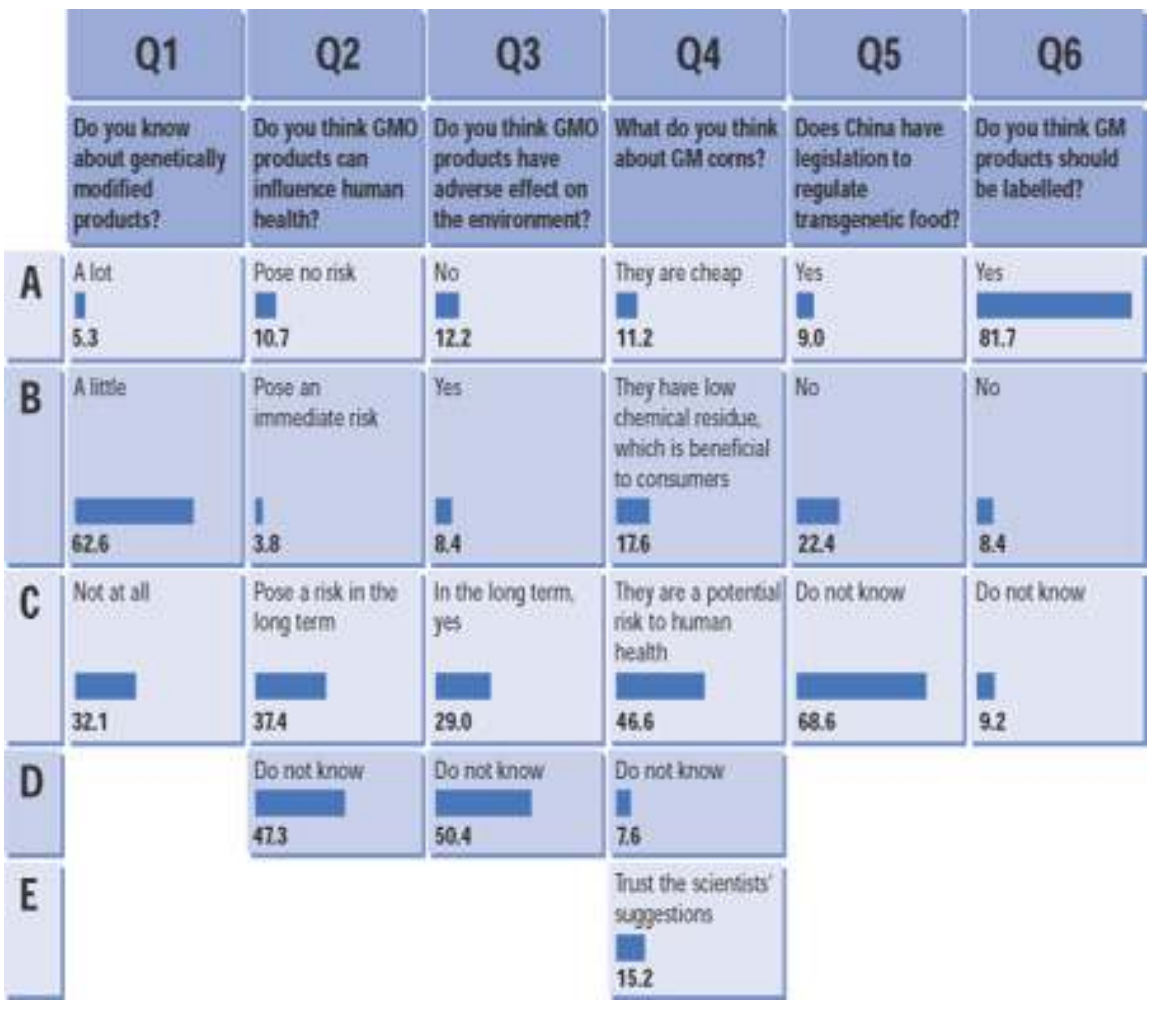

Source: author's survey

21 China is one of the largest importers of US soybeans. However, the new regulations may mean a big drop in this import. China's restrictions on GM soybeans have already had an impact on the importation of soybeans from the United States because $74 \% \mathrm{t}$ of US soybeans are genetically modified. From March to August 2002, the import of US soybeans dropped sharply. At the same time, the domestic price of soybeans increased rapidly. The requirements have even halted imports of US soybeans to China in some months of 2002. Shipments of US soybeans to China were suspended since early February 2002, although they continued after July. Although an interim agreement negotiated by the US in March 2002 allowed a nine-month grace period for imports to continue, the US traders criticised the rules. Despite attempts at clarification, US traders still complain that the rules are not explicit or practical and demand more specific stipulations and clarifying explanations from the Chinese authorities. Furthermore, among the GMOs that must be labelled according to the Administration Measures on the Labelling of Agro-GMOs, China produces only Bt cotton seed and tomatoes. All other relevant products are imported. Thus, the regulations and the supporting measures may not greatly affect China's domestic producers, but they will hurt US traders. 

soybeans, weak domestic prices in China for soybeans had squeezed crushing margins to almost nothing. China imported 10,420,000 tons of soybeans in 2002 ( $35.9 \%$ of China's domestic consumption), and more than $40 \%$ of these were genetically modified. The very same year, with the halt of soybean imports, the price of soybeans in China rose to 2,200 yuan and even 2,500 yuan a ton, much higher than the price of imported US soybeans. Domestic demand may thus force China's government to import even more soybeans.

Society and ethics

Some individuals and institutes see GM products as an approach to help solve environmental problems and problems of hunger. China is a developing country with 1.3 billion people, and genetic engineering may be a way of increasing its food security. If China wants to avoid dependence on imported crops to satisfy future domestic food needs, it should invest heavily in biotechnology research including genetic engineering. Food was in constant short supply due to limited investment, and backward science and technology. The ability to utilise the international market was also limited due to the policy of self-sufficiency. Thus basic policy has been to instigate all possible forces to increase grain output and solve the food security problem in the long term. After more than two decades of reform and development, grain production conditions and capabilities have improved greatly. Furthermore, tremendous changes have taken place in the international environment. Economic globalisation is incorporating China into the international economic cycle. China has rapidly become industrialised, commercialised and integrated into the world economy. After becoming a member of the WTO, the Chinese government is attaching a great deal of importance to food safety. Economic reform has transformed China's economy, raising incomes and reducing incidence of poverty. That the rise in family incomes has improved the nutritional status of the Chinese is no better illustrated than by the increase in the average heights of school-age children, as measured in large-scale surveys since the late 1970s. The profound changes in the background of China's food security demand changes in the understanding of food security and thus corresponding changes in strategy options and policies. At the same time, economic transformation has given rise to new patterns of social moral principles and values. These new social moral principles and values about biotechnology may be different from traditional Chinese ethics, in that a new form biotechnology that can lead to high crop productivity is not necessarily an acceptable one. The Chinese public now pays more attention to food quality than to quantity.

An area of study that influences the acceptability of biotechnology to the public can be called ethics consisting of a set of moral principles and values. Even though there are more disputes regarding biotechnology in the field of medicine than in agriculture and food sectors, GMOs trigger widespread controversy in world agriculture and food security. The Nuffield council in London conducted an examination of the ethical issues raised by newly developed biotechnology used in agriculture. It managed its discussion by three main ethical principles: The principle of general human welfare, the principle of people's rights and the principle of justice. Conference delegates did not think there was enough evidence of actual or potential harm occasioned by GMOs to human health 
or to the environment. However they urged a public policy to guide and regulate the way genetic engineering technology can be applied to address public concerns. In China, the government has developed a safety committee for agricultural biological genetic engineering to handle the evaluation of the safety of laboratory experiments, environmental release and commercial production of agricultural biotechnology products. Regulations on the administration of the safety of agricultural GMOs signed by premier Zhu Rongji went into effect on June $7^{\text {th }} 2001$. The regulations require that GMO products are labelled. However, a survey on Chinese consumer attitudes to GMOs discovered that a large proportion of China's public are uncomfortable with GMOs despite the presence of such strict regulations. The survey employed a scale which measured individual reactions to GMOs in China, and used responses from 200 men and women in Nanjing and rural areas around the city: $81.7 \%$ of people surveyed wanted to see labels on GMO products, $46.6 \%$ tended not to purchase GM corn due to the potential health risk it posed, and only $17.6 \%$ accepted GM corn for "low chemical residue". The results of the survey also indicate that a large number of persons did not know that transgenetic food is potentially harmful to human health.

The results of this survey showed tendencies in public attitudes to GMOs in China. Apart from showing China's consumers need more information about GMOs, it also indicated that GM foods probably will not become favourable products in China. If the government does decide to go further down the GM path, it must provide evidence that GM products pose no risk to human health.

THIS ARTICLE has explored the economic and social impact of GMO products in China. It looked at the economic effects of GMO plants, international trade in GMO products and public feeling about GMO products in China. The article also considered the impact of Bt cotton varieties on pesticide use, the effectiveness of pesticides on yields, and independent effect of the GM cotton on yields. It highlighted the great importance of market access if GMO producers are to exploit export opportunities, and looked at ethical issues and their impact on Chinese society. The article did not however provide any direct evidence of the impact of biotechnology on the Chinese food supply. Cotton and tobacco-the two crops in which China reportedly produces large volumes of genetically engineered crops-are not food crops. We could therefore provide no evidence that biotechnology has had a direct impact on food production in China so far, even though it has significantly influenced GM food importation policy.

\section{NOTES}

1. These data were provided by the the regulation project of the Environmental Protection Bureau of the Jiangsu provincial government.

2. Hang Jikun, Scott Rozelle, Carl Pray and Wang Qinfang, "Plant Biotechnology in China", Science, Vol. 295, January $25^{\text {th }}$ 2002, p. 675.

3. Ibid. 
4. The authors acknowledge the support of the Environmental Protection Bureau of the Jiangsu provincial government.

5. Another possible explanation for this discrepancy may be different survey methods. The data of the first and second tables were collected in a field survey by CAAS, while the data in the third table were collected by the author. Also the data on ordinary cotton do not correspond with those provided by the annual survey of the Price Bureau or other statistical yearbooks because the official data may include both genetic and non-genetic cotton. Most cotton in Shandong and Hebei provinces is Bt cotton and about $85.6 \%$ of cotton in Shandong province is Bt cotton in 1999. According to this data, the big gap between the data on the cost of pesticides in Table 2 and the data in the annual survey of the Price Bureau is explained by the average cost of pesticides which are similar to that for non Bt cotton. All the data in the tables was collected from the Bt cotton plant in China; see Carl E. Pray, Ma Danmeng, Huang Jikun and Qiao Fangbin, “The Impact of Bt Cotton in China", World Development, Vol. 29, No. 5, May 2001, pp. 813-825.

6. John E. Losey, Linda S. Rayor and Maureen E. Carter, “Transgenic Pollen Harms Monarque Larvae", Nature, No. 399, May 20 th 1999, p. 214. 